\title{
MICROTROMBICULA PELTIFERA, A NEW SUBSTITUTE NAME FOR M. MICROSCUTA STEKOLNIKOV, AL-GHAMDI, ALAGAILI AND MAKEPEACE, 2019 (ACARIFORMES, TROMBICULIDAE)
}

\author{
Alexandr A. Stekolnikov ${ }^{*}$ and Karl-Heinz Schmidt ${ }^{2}$ \\ ${ }^{1}$ Zoological Institute, Russian Academy of Sciences, St. Petersburg, Russia \\ ${ }^{2}$ Independent Researcher, Oderwitz, Germany \\ *corresponding author; e-mail: alexandr.stekolnikov@zin.ru
}

ABSTRACT: Microtrombicula peltifera nom.n. is proposed as a new substitute name to replace M. microscuta Stekolnikov, AlGhamdi, Alagaili and Makepeace, 2019, which was found to be a junior homonym of M. microscuta Zhao, Liang and Qu, 1989. Morphological differences between M. peltifera and M. microscuta are given.

KEY WORDS: Chigger mites, taxonomy, nomenclature, junior homonym.

DOI: 10.21684/0132-8077-2021-29-2-269-270

\section{INTRODUCTION}

Microtrombicula Ewing, 1950 is a worldwidedistributed genus of chigger mites that includes 208 known species (Nielsen et al. 2021). Its last revision on a world level was published more than a half of century ago (Vercammen-Grandjean 1965). The above work regarded 104 species (not counting subspecies) currently belonging to Microtrombicula, i.e. half of the species described to date. The genus Eltonella Audy, 1956, which was reviewed by VercammenGrandjean (1965) together with Microtrombicula, was included into Microtrombicula by Nadchatram and Dohany (1974). Marcandrea Vercammen-Grandjean, 1960 proposed as a subgenus of Eltonella (Vercammen-Grandjean 1960) has been raised to genus by Stekolnikov (2018).

In the first report on the chiggers of Saudi Arabia (Stekolnikov et al. 2019), Microtrombicula microscuta Stekolnikov, Al-Ghamdi, Alagaili and Makepeace, 2019 was described from the ears of Acomys dimidiatus (Cretzschmar) (Rodentia: Muridae). We have discovered that a species with the same name, Microtrombicula microscuta Zhao, Liang and Qu, 1989 had previously been described from China (Zhao et al. 1989) ex nasal fossae of Hipposideros bicolor (Temminck) (Chiroptera: Hipposideridae). Therefore, the former species name is a junior homonym of the latter. Since the name M. microscuta Stekolnikov, Al-Ghamdi, Alagaili and Makepeace, 2019 has no available junior synonyms, we propose the name Microtrombicula peltifera nom.n. as a substitute for it.

\section{SYSTEMATICS}

Etymology. The species name peltifera is derived from the Greek pelte - a small, light infantry shield, and phérō - to carry. The epithet thus means "carrying a small shield", which is equivalent to the meaning of microscuta.

The species M. microscuta Zhao, Liang and Qu, 1989 was included in the monograph on the trombiculid mites of China (Li et al. 1997), but was omitted from the world checklist of Trombiculidae (Nielsen et al. 2021). Since this species has also been overlooked during the description of M. microscuta Stekolnikov, Al-Ghamdi, Alagaili and Makepeace, 2019 (syn. of M. peltifera nom.n.), we provide below a short comparison of these species. Microtrombicula peltifera differs from M. microscuta Zhao, Liang and Qu, 1989 in having: a much lesser number of idiosomal setae (26-30 dorsal and 24-26 ventral vs. 44-50 dorsal and 29-34 ventral; sum 50-54 vs. 73-84); two posthumeral rows simple, with six setae each (vs. double, consisting of 18-21 and 10-12 setae, respectively); branched palpal genual and ventral palpal tibial setae $(\mathrm{fP}=\mathrm{B} / \mathrm{B} / \mathrm{NNB})$ (vs. nude, $\mathrm{fP} p=\mathrm{B} / \mathrm{N} / \mathrm{NNN}$ ); palpal claw with three (vs. two) prongs; sensilla (trichobothria) forked (vs. nude); three (vs. two) genualae I $(\sigma)$; seta on leg coxa II nude (vs. branched); one (vs. two: one nude and one with basal cilia) mastitarsala on leg tarsus III.

\section{ACKNOWLEDGEMENTS}

This research was supported by the Ministry of Science and Higher Education of the Russian Federation (grant No. AAAA-A19-11902079 0133-6, issued to AAS).

\section{REFERENCES}

Li, J., Wang, D. and Chen, X. 1997. Trombiculid mites of China: Studies on vector and pathogen of tsutsu- 


\section{A. A. Stekolnikov and K.-H. Schmidt}

gamushi disease. Guangdong Science and Technology Press, Guangzhou, 570 pp. [In Chinese]

Nadchatram, M. and Dohany, A.L. 1974. A pictorial key to the subfamilies, genera and subgenera of Southeast Asian chiggers (Acari, Prostigmata, Trombiculidae). Bulletin of the Institute for Medical Research, Malaysia, 16: 1-67.

Nielsen, D.H., Robbins, R.G. and Rueda, L.M. 2021. Annotated world checklist of the Trombiculidae and Leeuwenhoekiidae (1758-2021) (Acari: Trombiculoidea), with notes on nomenclature, taxonomy, and distribution. Zootaxa, 4967(1): 1-243.

Stekolnikov, A.A. 2018. Taxonomy and distribution of African chiggers (Acariformes, Trombiculidae). European Journal of Taxonomy, 395: 1-233.

Stekolnikov, A.A., Al-Ghamdi, S.Q., Alagaili, A.N. and Makepeace, B.L. 2019. First data on chigger mites
(Acariformes: Trombiculidae) of Saudi Arabia, with a description of four new species. Systematic and Applied Acarology, 24(10): 1937-1963.

Vercammen-Grandjean, P.H. 1960. Introduction à un essai de classification rationnelle des larves de Trombiculinae Ewing, 1944 (Acarina: Trombiculidae). Acarologia, 2(4): 469-471.

Vercammen-Grandjean, P.H. 1965. Revision of the genera: Eltonella Audy, 1956 and Microtrombicula Ewing, 1950, with descriptions of fifty new species and transferal of subgenus Chiroptella to genus Leptotrombidium (Acarina, Trombiculidae). Acarologia, 7 (suppl.): 34-257.

Zhao, S.-X., Liang, J.-Z. and Qu, Y. 1989. A new species of Microtrombicula Ewing, 1950 (Acari: Trombiculidae). Acta Entomologica Sinica, 32(4): 488-491. 